\title{
Implementing Universal Instructional Design In Postsecondary Courses And Curricula
}

Jeanne L. Higbee, University of Minnesota, USA

\begin{abstract}
This paper provides an introduction to Universal Instructional Design, an adaptation of the architectural concept of universal design, and discusses the benefits of this model as an inclusive approach to higher education. Electronic links to free resources are provided in the reference list.
\end{abstract}

Keywords: Pedagogy, Disability, Universal Design, Universal Instructional Design, Multicultural Education, Social Justice Model

\section{INTRODUCTION}

थ niversal design (UD) originated in the field of architecture as a proactive means of responding to legislated architectural requirements as well as societal and economic changes that called for providing access for people with disabilities (Center for Universal Design [CUD], 2007). When implementing universal design, the architect considers the needs of all potential users in developing the plans for a space so that it will not require retrofitting later. Architects found that when providing an architectural feature to enhance accessibility and inclusion for one population, all occupants or participants frequently benefit. One of the most common examples used to illustrate this concept is the curb cut (Johnson \& Fox, 2003), which was designed to enhance the mobility of people using wheelchairs. Many people appreciate the availability of ramps and curb cuts when making deliveries, pulling luggage, pushing a baby stroller, or engaging in almost any activity that involves the use of wheels. Similarly, other adaptations such as levered door handles instead of knobs, automatic door openers, and drinking fountains at varying heights are conveniences that can benefit many people.

After the passage of the Americans with Disabilities Act (ADA) in 1990, postsecondary institutions in the U.S. were challenged to make their campuses physically accessible. By 2003-2004, the U.S. National Center for Education Statistics (NCES) reported that $11.3 \%$ of undergraduate students in the U.S. had disabilities (Horn, Nevill, \& Griffin, 2006). Of these, 3.8\% had visual disabilities, 5.0\% had hearing impairments, $0.4 \%$ had speech impairments, $25.4 \%$ had orthopedic disabilities, $7.5 \%$ had learning disabilities, $11.0 \%$ had Attention Deficit Disorder (ADD), $21.9 \%$ had a mental illness or depression, $17.3 \%$ had health impairments, and $7.8 \%$ indicated "other" (Horn et al.).

The ADA requires not only physical spaces to be accessible, but that courses, curricula, and academic programs be accessible as well for students with all types of documented disabilities. Although the legislation referred to is specific to the U.S., similar laws have been enacted in other countries (e.g., the United Kingdom's Disability Discrimination Acts of 1995 and 2005, Directgov, n.d.). Meanwhile, the United Nations (UN) has established an international civil rights convention on the rights of people with disabilities (UN Enable, n.d.). Thus, many nations are prioritizing educational access for people with disabilities and people from other populations that historically have been underserved by higher education systems throughout the world (Ferrier \& Heagney, 2008; David, in press). Article 2 of the UN Convention on the Rights and Dignity of Persons with Disabilities (UN Enable, n.d.) provides definitions of key terms, including universal design: 
"Universal design means the design of products, environments, programmes and services to be usable by all people, to the greatest extent possible, without the need for adaptation or specialized design. "Universal design" shall not exclude assistive devices for particular groups of persons with disabilities where this is needed. (UN Enable, n.d.)

As one means of achieving the goal of improved access, universal design principles (CUD, 1997) have been adapted to education through a number of models that emerged in the last decade, including Universal Design for Learning (UDL; Center for Applied Special Technology, n.d.; Rose, 2001; Rose, Harbour, Johnston, Daley, \& Abarbanell, 2008; Rose \& Meyer, 2000), Universal Design of Instruction (UDI; Burgstahler \& Cory, 2008; Scott, McGuire, \& Shaw, 2001, 2003), and Universal Instructional Design (UID; Silver, Bourke, \& Strehorn, 1998). Meanwhile, through its demonstration projects to ensure students with disabilities receive a quality higher education, the U. S. Department of Education (n.d.) has provided funding for projects to implement these models in a variety of settings, including the "Pedagogy and Student Services for Institutional Transformation" (PASS IT, n.d.) project at the University of Minnesota.

This paper focuses specifically on UID, which primarily emphasizes inclusive pedagogy rather than structural features such as ramps or appropriate heights for signs, desks, counters, and shelves, or technological accommodations such as screen readers or captioning on videos. The "universal" in UID is not meant to imply that "one size fits all"; instead the goal of UID is universal access. Thus, in developing a course, curriculum, or academic support program, the educator takes into consideration the potential needs of all students, thinking inclusively about students' diverse social identities. Just as implementation of UD in architecture will hopefully eliminate the need to retrofit physical structures, one goal of UID is to reduce or eliminate the need for individual academic accommodations for students with disabilities, and particularly those practices that may inadvertently identify or segregate these students. Academic accommodations such as providing copies of notes or PowerPoint slides in advance of lecture or extended time on tests, which are often recommended for students with such disabilities as Attention Deficit Hyperactivity Disorder (ADHD), acquired brain injury, or dyslexia, can enhance learning and facilitate the demonstration of knowledge for many students. Although implementation of UID may not eliminate the need for sign language interpreters, books in Braille or on tape, and other accommodations that are part of daily living for people with disabilities, it can prompt educators to reconsider teaching methods that tend to exclude some students unnecessarily.

\section{GUIDING PRINCIPLES OF UNIVERSAL INSTRUCTIONAL DESIGN}

UID's guiding principles are based on the work of Chickering and Gamson (1987) and include: (a) creating a respectful and welcoming climate for learning; (b) determining the essential components of a course, curriculum, or program; (c) communicating clear expectations; (d) designing teaching methods that consider diverse learning styles, abilities, ways of knowing, and previous experience and background knowledge; (e) exploring the use of natural supports for learning, including technology, to enhance opportunities for all learners; (f) creating multiple ways for students to demonstrate their knowledge; (g) providing constructive feedback; and (h) promoting interaction among and between faculty and students (Fox, Hatfield, \& Collins, 2003). Clearly, these are basic strategies for good teaching. However, even for the most reflective faculty members, implementing UID requires a heightened level of intentionality:

UID has simultaneously broadened and focused our thinking. We think more broadly about the diversity of our students and how students' social identities can shape their learning experiences, and meanwhile we are also more focused on how we can ensure that no students are excluded or marginalized. (Higbee \& Goff, 2008, p. 2)

This paper discusses the implementation of UID's guiding principles (Goff \& Higbee, 2008; Higbee, 2003; Higbee \& Goff, 2008) and presents one faculty member's efforts to assess student perceptions of the effectiveness of UID as a model for inclusion.

\section{Creating a Respectful and Welcoming Climate for Learning}

There are many obvious steps an instructor can take to welcome students, whether in a small discussion- 
based class or a large lecture. Arriving early and welcoming students as they enter, especially on the first day of class, can set the tone for the weeks to follow. If available, faculty can study photographs of enrolled students prior to the first day of class, and then refer to the photos throughout the term in order to assist in learning each student's name, thus conveying that each individual with his or her complex and multifaceted social identity is unique and important. If a class is too large for individual student introductions, the instructor can still provide time for students in a lecture hall to introduce themselves to the other students sitting in close proximity.

The course syllabus can also play an important role in creating a welcoming atmosphere. In the Department of Postsecondary Teaching and Learning (PsTL) at the University of Minnesota, many faculty members begin their syllabi with "Welcome to PsTL XXXX ..." at the very top of the page, even before instructor contact information, thus articulating that being welcoming is a high priority. This also sets the stage for discussing the syllabus on the first day of class, beginning by welcoming students to the class. Pedelty (2008) has suggested "performing" the syllabus, including addressing topics of importance to a diverse student population, such as absences for the observance of religious holidays and accommodations for students with disabilities. It is imperative that students with disabilities believe that instructors are committed to providing equitable learning opportunities for all students. Disclosing a disability - particularly a "hidden" disability (Lee \& Jackson, 1992; Spencer \& Romero, 2008; Wieland, 2009) — can be a very difficult and highly personal decision (Alexandrin, Schreiber, \& Henry, 2008; Uncertain welcome, 2002). Too often students wait to "test the water" before disclosing that they need accommodations, and by then they may have already fallen behind or earned grades that will be hard to overcome. If students with disabilities believe that faculty have positive attitudes toward them as students and toward providing the necessary accommodations to ensure their success (Kalivoda \& Higbee, 1995, 1998), they are more likely to seek appropriate assistance at the beginning of the term.

Language is an important factor in communicating a respectful environment for learning (Tregoning, 2009). The American Psychological Association (2001) urges the use of "person-first" language to avoid labeling people on the basis of a single feature of their diverse and complex social identities. Thus, in this paper I refer to "students with disabilities" rather than "disabled students." Beyond labels, there are other language issues specific to how disability as a social identity is portrayed. People who would not consider it socially acceptable to say, "That's so gay" do not think twice about using the phrase, "That's so lame!" Lame and dumb are but two frequently used words that equate having a disability with being stupid. Similarly, phrases like "the blind leading the blind" convey that people with disabilities do not know what they are doing. Tregoning noted, "Some oppressive language about disability is neither subtle nor complicated. . . most people understand that terms like 'cripple,' 'deaf and dumb,' 'retard,' 'spaz,' or 'nut case' are derogatory and therefore not appropriate. The difficulty comes when one starts to discuss more subtle terminology" (p. 173). For example, in the context of disability, referring to someone without a disability as "normal" insinuates that the person with a disability is "abnormal", perpetuating the medical model of disability as a deficit - something to be "cured"-rather than viewing disability through the lens of a social justice model that recognizes disability as a social construction (Evans, 2008; Hackman, 2008). The attitudes of others are often the most difficult barriers that people with disabilities must overcome. Use of inappropriate language is one of the ways that negative attitudes are communicated.

Physical logistics are also necessary considerations in creating welcoming classrooms for students with disabilities. Factors ranging from entry ways and aisles that can be navigated in a wheelchair or scooter and appropriate seating and writing surfaces to lighting and signage can influence students' comfort levels. In addition, it is critical that course Web sites and any words and images to be projected on a screen in class are accessible (Goff, 2008; Kalivoda, Totty, \& Higbee, 2009; Shapiro, 2008). For example, PowerPoint presentations that are intended to be visually stimulating may be distracting for a student with Attention Deficit Hyperactivity Disorder (ADHD) or unreadable to a student with low vision or a student accessing the presentation electronically via a screen reader.

From the perspective of UID, it is understood that steps taken to include and engage students with disabilities in the classroom enhance learning for all students. Creating respectful and welcoming learning environments promotes positive attitudes toward learning. Facilitating conversations about language use and involving students in establishing guidelines for respectful communication benefit everyone and assist students in building skills that will be useful throughout their lives. 


\section{Determining Essential Course Components}

Essential course components can include both subject matter and pedagogy. Course requirements vary substantially and may involve national and international standards for the academic discipline as well institutional requirements. Some courses serve as prerequisites for subsequent coursework, so students must master the material in order to progress successfully through the curriculum. However, how students demonstrate mastery may not be prescribed. For example, in a biology course for non-science majors, is the dissection of animals essential? Given new technologies, can laboratories be virtual? Must a student be able to wield a scalpel in order to demonstrate learning? Are aspects of the course considered essential only because that is how things have always been done? By rethinking pedagogy, it is possible to find ways to ensure that all students have the opportunity to participate (Hatch, Ghere, \& Jirik, 2008).

One of the most common issues that arise in discussion of essential components is the question of time. Does how quickly the student masters the material or performs a task matter? Extended time on tests is a common academic accommodation for students with a wide range of disabilities from mobility impairments to learning disabilities. Time limitations can also result in lower grades for students who are not native speakers of the language in use in the classroom, students who have test anxiety, and students who like to process information slowly in order to achieve a deeper level of understanding. Depending on the course, there may not be any reason to limit the time to complete a test except the length of the class period. In that case, can the tests be made shorter, be administered online, or can some other solution be found so that all students can have the time they need to demonstrate their knowledge? In most courses, how much the student knows should be more important than how fast the student can write or fill in an answer sheet. There are exceptions; for a student in nursing, for example, speed may be essential in saving a life. But in many courses faculty may promote learning by reconsidering the role that time plays in assessing student knowledge. Meanwhile, some students with disabilities who would otherwise be segregated in separate testing rooms may be able to remain in the classroom on exam days. When students are consistently absent from the classroom on the days that tests and quizzes are given, the likelihood that their disability status will remain confidential is in doubt.

\section{Communicating Clear Expectations}

Students often find themselves in the position of trying to figure out what the teacher wants. For students with disabilities that impact the interpretation of nonverbal cues or the retention of information that is only presented orally this can be particularly frustrating. Faculty who believe that they have provided clear directions for an assignment can also be frustrated by students' questions. Students want to know exactly what is expected and how their work will be evaluated. Sometimes an assignment is intentionally ambiguous in order to stimulate student creativity. But to the extent possible, it is important to clarify in writing and orally the grading rubrics for assignments and both the format and content areas for tests. Putting the expectations on a handout, projecting them on a screen in class, posting them to the course Web site, disseminating them in an e-mail blast, and discussing them in person can ensure that all students understand.

Students also want details. They do not want to read that four essays make up 50\% of their course grade; they want to know precisely how the grade will be calculated. Is there a point system? Is each essay weighted equally? In addition to the syllabus, it can be helpful to provide students with a spreadsheet of all assignments with due date and point value and encourage students to track their own progress by teaching them how their grades are calculated (Goff \& Higbee, 2008, p. 10; Higbee, 2008).

In addition to academic expectations, institutions also have expectations regarding student behavior. The growing number of students with Autism-spectrum disorders, psychiatric disorders, and other disabilities that can be manifested in social as well as academic behaviors adds a new dimension to conversations about civility in the classroom. Involving students in establishing behavioral guidelines can facilitate "buy in" (Goff \& Higbee, 2008; Higbee, 2008). However, some students with disabilities do not recognize the degree to which their behavior might be disruptive. It is important for faculty to meet with students privately to discuss these issues, and may also be helpful to include an advocate or a staff member from the institution's disability resource office in the conversation. 


\section{Using Diverse Teaching Methods}

Culturally-responsive teaching involves designing teaching methods that consider diverse learning styles, abilities, ways of knowing, and the previous experience and background knowledge of the student so that knowledge construction can be a collaborative effort. To the extent possible, faculty should endeavor to incorporate a wide array of teaching strategies in every course. When that is not possible, students should have a choice of different course sections that are adapted to different learning styles and ways of knowing, including the use of integrated skill development (Arendale \& Ghere, 2005; Barajas \& Jacobs, 2005; Chung, 2005; Hsu, 2005; James, 2005); inquiry-based or problem-based learning (Higbee, Chung, \& Hsu, 2008; Hsu, 2005; Staats, 2005); simulations (Arendale \& Ghere, 2005, 2008; Miksch, 2008); civic engagement (Barajas, 2002, 2005); experiential learning (Sharby \& Roush, 2008); metaphoric thinking (James, 2005; James \& Kader, 2008); intergroup dialogue (Higbee \& Barajas, 2007; Zuñiga, 2003) and other dialogic approaches (Bruch \& Reynolds, 2005); and computer-based instruction (Brothen \& Wambach, 2008; Kinney \& Kinney, 2008; Kinney, Kinney, \& Robertson, 2005).

\section{Providing Natural Supports}

Natural supports for learning can include everything from course handouts and study guides (Higbee, Chung, \& Hsu, 2008) to Supplemental Instruction (Stone \& Jacobs, 2006). In recent decades there has been an increasing dependence on instructional technologies (Smith, 1997), which when teaching students with disabilities also requires knowledge concerning assistive technologies (Kalivoda, Totty, \& Higbee, 2009; Knox, Kalivoda, Higbee, \& Totty, 2000). Duquaine-Watson (2008) has warned educators about how technological supports can sometimes widen the gap rather than narrowing it. Faculty must be aware of limitations in students' access to technology and knowledge of how to use various forms of technology.

\section{Creating Multiple Means for Demonstrating Knowledge}

When considering how students may be able to demonstrate knowledge, it is important to go back to thinking about the essential components of the course. Do assessment strategies provide information about what students have learned and the skills they have developed? Examinations can have many formats (e.g., essay, short answer, problem-based, multiple choice, lab practical), and assessment can also take other forms (Goff \& Higbee, 2008). Students can engage in group projects, write papers, develop multimedia presentations, create works of art, and so on. To the extent possible, students should be given opportunities to demonstrate their knowledge in ways that reflect their own preferred learning styles and ways of knowing. Doing so also better prepares students for the world of work, where their performance will be evaluated in myriad ways, but seldom if ever through objective testing.

\section{Providing Constructive Feedback}

Feedback has many purposes. In addition to informing students about their academic standing in a course, formative feedback can enhance the learning process and assist students in understanding the connections between learning and demonstrating knowledge and assessing their own growth. Feedback can also come in many forms. For example, in "Successful Undergraduate Mathematics Through Universal Design of Essential Course Components, Pedagogy, and Assessment" Duranczyk and Fayon (2008) developed a rubric that directly links student learning to teaching standards in mathematics. In "Writing Assignments and Universal Design for Instruction: Making the Phantom Visible" DeLong (2008) articulated the need to make the implicit explicit so that students can have a better understanding of the feedback they are receiving.

\section{Promoting Interaction}

It is difficult to understand a student's ways of knowing without taking the time to get to know the student as an individual. Some faculty go about this by meeting individually with every student in the class (Arendale \& Ghere, 2005; Hsu, 2005). This practice eliminates the need to single out students with disabilities to discuss accommodations, and also communicates that the teacher cares about the academic achievement of each student. When teaching large numbers of students this approach may not be practical, but faculty can still get to know 
students through e-mail communication, reading student papers and journals, and welcoming students to office hours.

Promoting interaction among students is also important. Even in large lecture halls, students can pair up or work in small groups for some in-class activities. Interaction is one of the best ways for people to overcome their prejudices and become accepting of people with different social identities (Zuñiga, 2003). Although for some students - with or without disabilities - social interactions may be challenging or stressful, these activities provide the opportunity to get to know one another beyond the "label" of a specific social identity, whether based on race, ethnicity, gender, age, sexual orientation, religion, or disability.

\section{Just Good Teaching?}

Hodge and Preston-Sabin (1997) asked whether accommodations for students with disabilities are just good teaching. Similar questions arise when discussing UID. How is this model different from best practices for instruction? Perhaps the emphasis should not be on whether UID is merely good teaching, but instead on whether faculty members actually engage in these practices in very intentional and reflective ways that consider the strengths and challenges of all students and endeavor to ensure that all students have equitable opportunities to achieve academic success. When designing an "ice breaker" activity, does the faculty member consider potential students with mobility or communication impairments? Before selecting a film to show in class, do many faculty members check to make sure that the film is captioned and available with voice-over to describe the action on the screen through organizations like the Descriptive Video Service? If not, does the faculty member alter the lesson plan if there are students with hearing or vision impairments in the class? Does the faculty member then resent having to come up with an alternative plan at the last minute? Although these examples focus on students with disabilities, similar situations can arise when teaching students with a wide array of multifaceted social identities. For example, some of the same considerations in planning for teaching students with disabilities (e.g., extended time on tests) benefit students who are learning in a second, third, or fourth language. Returning to the example of dissection in biology classes, rethinking pedagogy can ensure inclusion for students with diverse religious beliefs as well as students with mobility or vision impairments. Assessing the implementation of UID can assist in determining whether the model goes beyond expectations for good teaching (Higbee, Lee, Bardill, \& Cardinal, 2008).

\section{ASSESSING OUTCOMES AND STUDENT PERCEPTIONS}

During the 2005-2006 academic year, 90\% of students without disabilities enrolled in courses at the University of Minnesota taught by faculty participating in the PASS IT project completed these courses with a passing grade, as did $88 \%$ of students with disabilities. Most of these faculty members had also been involved in a previous series of UID workshops as part of the Curriculum Transformation and Disability (CTAD) project (Higbee, 2003). In fall 2006, after these faculty members participated in 2006 PASS IT Summer Institute, the percentages went up to $92 \%$ and $90 \%$ respectively. Of the 31 students with disabilities included in the fall 2006 data set, 29 did not require any separate accommodations in the universally-designed classes.

Among students enrolled in courses taught throughout the U.S. by faculty who had participated in the 3-day PASS IT summer institutes in 2006 and 2007, 89\% of the students with documented disabilities completed the courses with passing grades, while $95 \%$ of the students without disabilities completed the courses with passing grades. In general, faculty participants reported seeing higher pass rates in their courses as well as higher teaching evaluations, and attributed these changes to the implementation of UID in their courses. However, without comparison data it is impossible to determine the impact of faculty professional development in UID accurately; further research at the course, institutional, and national levels is needed.

Student perceptions can also provide insights (Higbee, Lee, Bardill, \& Cardinal, 2008), so in addition to administering my institution's standardized evaluations of teaching, I conduct my own evaluations related to the implementation of UID guiding principles. Table 1 summarizes the results over 3 years of teaching a 3-week intensive course in psychology. The class sizes were small: 14 students in 2006, 17 in 2007, and 13 in 2008. However, the advantages of small class size were balanced by the disadvantage of meeting for 3 hours and 40 minutes every day - a challenge for students and faculty member alike. How does a teacher keep students engaged 
for such a long time period? In this case, using multiple teaching strategies was essential (Higbee, Chung, \& Hsu, 2008). In 2008 I added items related to the students' perception of the impact of implementing UID on them as individual learners. Table 2 presents the new data.

Table 1. Psychology course evaluations for 3-week May term: 2006, 2007, 2008

This course was designed using the principles of Universal Instructional Design (UID), a model for developing inclusive curricula. On a 1 to 10 scale, where $1=$ "not at all" and $10=$ "outstanding," please evaluate the extent to which PSTL 1280/1289 accomplished each of the following goals:

\begin{tabular}{|c|c|c|c|c|}
\hline Guiding Principle & $M$ & Mode & $M d n$ & Range \\
\hline $\begin{array}{l}\text { Dr. Higbee created a respectful and } \\
\text { welcoming learning environment. }\end{array}$ & 9.9 & 10 & 10 & $9-10$ \\
\hline The required course content was appropriate. & 9.6 & 10 & 10 & $8-10$ \\
\hline $\begin{array}{l}\text { The expectations for the course and how the assignments } \\
\text { and tests would be graded were clearly communicated } \\
\text { via the syllabus, summary of assignments, and separate } \\
\text { assignment sheets for each major assignment (e.g., grading } \\
\text { rubrics for study guides, essays, final project). }\end{array}$ & 9.9 & 10 & 10 & $9-10$ \\
\hline $\begin{array}{l}\text { Dr. Higbee provided timely, clear, and accurate } \\
\text { feedback (e.g., quizzes graded immediately, answer } \\
\text { keys provided, quick turn-around for grading papers. }\end{array}$ & 9.9 & 10 & 10 & $9-10$ \\
\hline $\begin{array}{l}\text { Natural supports for learning were provided } \\
\text { (e.g., instructor-created study guides, reviews for all } \\
\text { quizzes, class exercises to illustrate textbook content). }\end{array}$ & 9.8 & 10 & 10 & $8-10$ \\
\hline $\begin{array}{l}\text { Dr. Higbee used multiple teaching strategies (e.g., short } \\
\text { lecture, discussion, films, small group exercises). }\end{array}$ & 9.9 & 10 & 10 & $9-10$ \\
\hline $\begin{array}{l}\text { In PSTL } 1280 / 1289 \text { students were able to demonstrate } \\
\text { their knowledge and mastery of the material in } \\
\text { multiple ways (e.g., study guides, quizzes, essays, } \\
\text { final project, final exam). }\end{array}$ & 9.8 & 10 & 10 & $8-10$ \\
\hline $\begin{array}{l}\text { Dr. Higbee encouraged contact (e.g., discussion) among } \\
\text { students and between students and the faculty member } \\
\text { (e.g., via e-mail, provided home phone number). }\end{array}$ & 9.6 & 10 & 10 & $7-10$ \\
\hline
\end{tabular}
$n=44$

Table 2. Impact of UID on individual learning in a 3-week psychology course release

On a 1 to 10 scale, where $1=$ "not at all" and 10 = "very much so," please evaluate the extent to which the implementation of UID in PSTL 1289 had an impact on you personally.

To what extent do you believe that the implementation of UID in this course has enhanced your participation in the course?

To what extent do you believe that the implementation of UID in this course has enhanced your achievement in the course?

To what extent do you believe that the implementation of UID in this course has enhanced your belief that the instructor has a sincere interest in your learning?

How likely would you be to recommend this course to a friend? $n=13$

\section{$\underline{M} \quad \underline{\text { Mode }} \underline{M d n} \quad \underline{\text { Range }}$}

$\begin{array}{llll}8.3 & 10 & 9 & 5-10\end{array}$

$\begin{array}{llll}7.9 & 10 & 8 & 3-10\end{array}$

$\begin{array}{llll}9.3 & 10 & 10 & 7-10\end{array}$

$\begin{array}{llll}9.6 & 10 & 10 & 8-10\end{array}$ 
In summer 2008 students were also asked to respond to the following question: "Are there any specific ways in which you benefited from the implementation of UID in this course (e.g., enough time for everyone to complete quizzes; study guides linking quizzes and the text)?" Of the 13 students who completed the questionnaire, 9 responded. Three students specifically discussed the structure for the course. One wrote, "I think I benefited from the clear structure of the course; knowing what material needed to be studied each day is an example of this." Another asserted, "The employment of study guides worked very well for me, as they served to reinforce the information from the text in a clear and structured way." Also regarding the study guides, a student commented, "I was very appreciative of the link from the study guides and text to the actual quizzes. Sometimes a professor doesn't test on all of the material he/she has given you, which can be frustrating." Three students conveyed their appreciation for the "untimed quizzes." One wrote, "I loved having untimed quizzes that got rid of most of the stress that I had." Three students made more general comments related to teaching style, and specifically the minimal use of a lecture format. One summarized, "It is easier to learn in this format, rather than the way that other classes are taught." Another wrote, "Yes, I benefited in every way. The teaching style better fit our needs as a class as opposed to sitting through lecture." Finally, one of the students who had also commented on the format of the course concluded by writing, "I have thoroughly enjoyed the last two weeks. The learning environment was so comfortable; it made me want to be in class and want to learn the material- $\underline{\text { Thank You!" }}$

\section{CONCLUSION}

Implementing UID may require extra time during various stages of course planning. However, it can also save time in the long run by encouraging more thorough planning and eliminating the need to provide last-minute accommodations. Meanwhile, implementation of UID can enhance classroom climate and ensure that students with diverse ways of knowing have an equal opportunity to learn and to demonstrate their knowledge. Just as universal design as an architectural concept has opened doors for people with disabilities and others, UID has the potential to create barrier-free pathways for learning for students with and without disabilities.

\section{AUTHOR INFORMATION}

Jeanne L. Higbee is a professor in the Department of Postsecondary Teaching and Learning at the University of Minnesota. She is an ACPA-College Student Educators International Diamond Honoree and recipient of the ACPA Voice of Inclusion Medallion and Disability Ally Award, the College Reading and Learning Association Robert Griffin Award for Long and Outstanding Service, the Henry Young Award for Outstanding Individual Contribution to the National Association for Developmental Education, and NADE's Hunter R. Boylan Outstanding Research/Publication Award. Jeanne is the principal investigator for Pedagogy and Student Services for Institutional Transformation (PASS IT), funded by the U.S. Department of Education.

\section{REFERENCES}

1. Alexandrin, J. R., Schreiber, I. L., \& Henry, E. (2008). Why not disclose? In J. L. Higbee \& E. Goff (Eds.), Pedagogy and student services for institutional transformation: Implementing universal design in higher education (pp. 377-392). Minneapolis: University of Minnesota, Center for Research on Developmental Education and Urban Literacy. Retrieved April 24, 2009, from http://cehd.umn.edu/passit/docs/PASS-ITBook.pdf

2. American Psychological Association. (2001). Publication manual of the American Psychological Association $\left(5^{\text {th }}\right.$ ed.). Washington, DC: Author.

3. Arendale, D. R., \& Ghere, D. L. (2005). Integrating best practices of developmental education in introductory history courses. In J. L. Higbee, D. B. Lundell, \& D. R. Arendale (Eds.), The General College vision: Integrating intellectual growth, multicultural perspectives, and student development (pp. 223-246). Minneapolis: University of Minnesota, General College, Center for Research on Developmental Education and Urban Literacy. Retrieved April 22, 2009, from http://cehd.umn.edu/CRDEUL/pdf/TheGCVision/section3.pdf 
4. Arendale, D., \& Ghere, D. (2008). Teaching college history using Universal Instructional Design. In J. L. Higbee \& E. Goff (Eds.), Pedagogy and student services for institutional transformation: Implementing universal design in higher education (pp. 119-130). Minneapolis: University of Minnesota, Center for Research on Developmental Education and Urban Literacy. Retrieved April 24, 2009, from http://cehd.umn.edu/passit/docs/PASS-IT-Book.pdf

5. Barajas, H. L. (2002). Changing objects to subjects: Transgressing normative service learning approaches. In D. B. Lundell \& J. L. Higbee (Eds.), Exploring urban literacy and developmental education (pp. 25-32). Minneapolis: University of Minnesota, General College, Center for Research on Developmental Education and Urban Literacy. Retrieved April 22, 2009, from http://cehd.umn.edu/CRDEUL/pdf/monograph/3-a.pdf

6. Barajas, H. L. (2005). Creating spheres of freedom: Connecting developmental education, multicultural education, and student experience. In J. L. Higbee, D. B. Lundell, \& D. R. Arendale (Eds.), The General College vision: Integrating intellectual growth, multicultural perspectives, and student development (pp. 131-153). Minneapolis: University of Minnesota, General College, Center for Research on Developmental Education and Urban Literacy. Retrieved April 22, 2009, from http://cehd.umn.edu/CRDEUL/pdf/TheGCVision/section2.pdf

7. Barajas, H. L., \& Jacobs, W. R. (2005). Reading, writing, and sociology? Developmental education and the sociological imagination. In J. L. Higbee, D. B. Lundell, \& D. R. Arendale (Eds.), The General College vision: Integrating intellectual growth, multicultural perspectives, and student development (pp. 355-368). Minneapolis: University of Minnesota, General College, Center for Research on Developmental Education and Urban Literacy. Retrieved April 22, 2009, from http://cehd.umn.edu/CRDEUL/pdf/TheGCVision/section3.pdf

8. Brothen, T., \& Wambach, C. (2008). Universal Instructional Design in a computer-based psychology course. In J. L. Higbee \& E. Goff (Eds.), Pedagogy and student services for institutional transformation: Implementing universal design in higher education (pp. 165-181). Minneapolis: University of Minnesota, Center for Research on Developmental Education and Urban Literacy. Retrieved April 24, 2009, from http://cehd.umn.edu/passit/docs/PASS-IT-Book.pdf

9. Bruch, P., \& Reynolds, T. (2005). Multicultural writing instruction at the General College: A dialogical approach. In J. L. Higbee, D. B. Lundell, \& D. R. Arendale (Eds.), The General College vision: Integrating intellectual growth, multicultural perspectives, and student development (pp. 201-218). Minneapolis: University of Minnesota, General College, Center for Research on Developmental Education and Urban Literacy. Retrieved April 22, 2009, from http://cehd.umn.edu/CRDEUL/pdf/TheGCVision/section2.pdf

10. Burgstahler, S. E., \& Cory, R. C. (2008). Universal design in higher education: From principles to practice. Cambridge, MA: Harvard Education Press.

11. Center for Applied Special Technology. (n.d.). UDL questions and answers. Retrieved November 29, 2007, from http://www.cast.org/research/faq/index.html

12. The Center for Universal Design. (2007). About UD: Universal design history. Raleigh: North Carolina State University. Retrieved November 29, 2007, from http://www.design.ncsu.edu/cud/about_ud/udhistory.htm

13. The Center for Universal Design. (1997). The principles of universal design (Version 2.0). Raleigh: North Carolina State University. Retrieved December 11, 2006, from http://www.design.ncsu.edu/cud/about ud/udprinciplestext.htm

14. Chickering, A. W., \& Gamson, Z. F. (1987). Seven principles for good practice in undergraduate education. AAHE Bulletin, 39(7), 3-7.

15. Chung, C. J. (2005). Integrating and enabling skill development in a symbolic logic class. In J. L. Higbee, D. B. Lundell, \& D. R. Arendale (Eds.), The General College vision: Integrating intellectual growth, multicultural perspectives, and student development (pp. 319-332). Minneapolis: University of Minnesota, General College, Center for Research on Developmental Education and Urban Literacy. Retrieved April 22, 2009, from http://cehd.umn.edu/CRDEUL/pdf/TheGCVision/section3.pdf

16. David, M. E. (Ed.). (in press). Improving learning by widening participation in higher education. London, UK: Routledge/Taylor Francis Group. 
17. DeLong, R. (2008). Writing assignments and universal design for instruction: Making the phantom visible. In J. L. Higbee \& E. Goff (Eds.), Pedagogy and student services for institutional transformation: Implementing universal design in higher education (pp. 131-136). Minneapolis: University of Minnesota, Center for Research on Developmental Education and Urban Literacy. Retrieved April 24, 2009, from http://cehd.umn.edu/passit/docs/PASS-IT-Book.pdf

18. Directgov. (n.d.). The Disability Discrimination Act. (n.d.). Retrieved April 23, 2009, from http://www.direct.gov.uk/en/DisabledPeople/RightsAndObligations/DisabilityRights/DG_4001068

19. Duquaine-Watson, J. M. (2008). Computing technologies, the digital divide, and "universal" instructional methods. In J. L. Higbee \& E. Goff (Eds.), Pedagogy and student services for institutional transformation: Implementing universal design in higher education (pp. 437-449). Minneapolis: University of Minnesota, Center for Research on Developmental Education and Urban Literacy. Retrieved April 24, 2009, from http://cehd.umn.edu/passit/docs/PASS-IT-Book.pdf

20. Duranczyk, I. M., \& Fayon, A. K. (2008). Successful undergraduate mathematics through universal design of essential course components, pedagogy, and assessment. In J. L. Higbee \& E. Goff (Eds.), Pedagogy and student services for institutional transformation: Implementing universal design in higher education (pp. 137-153). Minneapolis: University of Minnesota, Center for Research on Developmental Education and Urban Literacy. Retrieved April 24, 2009, from http://cehd.umn.edu/passit/docs/PASS-IT-Book.pdf

21. Evans, N. J. (2008). Theoretical foundations of Universal Instructional Design. In J. L. Higbee \& E. Goff (Eds.), Pedagogy and student services for institutional transformation: Implementing universal design in higher education (pp. 11-23). Minneapolis: University of Minnesota, Center for Research on Developmental Education and Urban Literacy. Retrieved April 24, 2009, from http://cehd.umn.edu/passit/docs/PASS-IT-Book.pdf

22. Ferrier, F., \& Heagney, M. (Eds.). (2008). Higher education in diverse communities: Global perspectives, local initiatives. London, UK: European Access Network and Higher Education Authority of Ireland, in cooperation with Masaryk University Press.

23. Fox, J. A., Hatfield, J. P., \& Collins, T. C. (2003). Developing the Curriculum Transformation and Disability (CTAD) workshop model. In J. L. Higbee (Ed.), Curriculum transformation and disability: Implementing universal design in higher education (pp. 23-39). Minneapolis: University of Minnesota, General College, Center for Research on Developmental Education and Urban Literacy. Retrieved November 29, 2007, from http://cehd.umn.edu/CRDEUL/books-ctad.html

24. Goff, E. (2008). Accessible PowerPoint presentations. In E. Goff \& J. L. Higbee (Eds.), Pedagogy and student services for institutional transformation: Implementation guidebook for faculty and instructional staff (pp. 81-83). Minneapolis: University of Minnesota, College of Education and Human Development. Available soon at http://cehd.umn.edu/passit/

25. Goff, E., \& Higbee, J. L. (Eds.). (2008). Pedagogy and student services for institutional transformation: Implementation guidebook for faculty and instructional staff. Minneapolis: University of Minnesota, College of Education and Human Development. Available soon at http://cehd.umn.edu/passit/

26. Hackman, H. W. (2008). Broadening the pathway to academic success: The critical intersection of Social Justice Education, Critical Multicultural Education, and Universal Instructional Design. In J. L. Higbee \& E. Goff (Eds.), Pedagogy and student services for institutional transformation: Implementing universal design in higher education (pp. 25-48). Minneapolis: University of Minnesota, Center for Research on Developmental Education and Urban Literacy. Retrieved April 24, 2009, from http://cehd.umn.edu/passit/docs/PASS-IT-Book.pdf

27. Hatch, J. T., Ghere, D. L., \& Jirik, K. N. (2008). Empowering students with severe disabilities: A case study. In J. L. Higbee \& E. Goff (Eds.), Pedagogy and student services for institutional transformation: Implementing universal design in higher education (pp. 393-403). Minneapolis: University of Minnesota, Center for Research on Developmental Education and Urban Literacy. Retrieved April 24, 2009, from http://cehd.umn.edu/passit/docs/PASS-IT-Book.pdf

28. Higbee, J. L. (Ed.). (2003). Curriculum transformation and disability: Implementing universal design in higher education. Minneapolis: University of Minnesota, General College, Center for Research on Developmental Education and Urban Literacy. Retrieved November 29, 2007, from http://cehd.umn.edu/CRDEUL/books-ctad.html 
29. Higbee, J. L. (2008). The faculty perspective: Implementing universal design in a first-year classroom. In S. E. Burgstahler \& R. C. Cory (Eds.), Universal design in higher education: From principles to practice (pp. 61-72). Cambridge, MA: Harvard Education Press.

30. Higbee, J. L., \& Barajas, H. L. (2007). Building effective places for multicultural learning. About Campus, 12(3), 16-22.

31. Higbee, J. L., Chung, C. J., \& Hsu, L. (2008). Enhancing the inclusiveness of first-year courses through Universal Instructional Design. In J. L. Higbee \& E. Goff (Eds.), Pedagogy and student services for institutional transformation: Implementing universal design in higher education (pp. 61-77). Minneapolis: University of Minnesota, Center for Research on Developmental Education and Urban Literacy. Retrieved April 24, 2009, from http://cehd.umn.edu/passit/docs/PASS-IT-Book.pdf

32. Higbee, J. L., \& Goff, E. (Eds.). (2008). Pedagogy and student services for institutional transformation: Implementing universal design in higher education. Minneapolis: University of Minnesota, Center for Research on Developmental Education and Urban Literacy. Retrieved April 24, 2009, from http://cehd.umn.edu/passit/docs/PASS-IT-Book.pdf

33. Higbee, J. L., Lee, P. H., Bardill, J. R., \& Cardinal. H. D. (2008). Student evaluations of the effectiveness of implementing Universal Instructional Design. In J. L. Higbee \& E. Goff (Eds.), Pedagogy and student services for institutional transformation: Implementing universal design in higher education (pp. 367-375). Minneapolis: University of Minnesota, Center for Research on Developmental Education and Urban Literacy. Retrieved April 24, 2009, from http://cehd.umn.edu/passit/docs/PASS-IT-Book.pdf

34. Hodge, B. M., \& Preston-Sabin, J. (1997). Accommodations-Or just good teaching? Strategies for teaching college students with disabilities. Westport, CT: Praeger.

35. Horn, L., Nevill, S., \& Griffin, J. (2006). Profile of undergraduates in U.S. postsecondary education institutions: 2003-04 with a special analysis of community college students. Washington, DC: U.S. Department of Education, National Center for Education Statistics, Institute of Education Sciences. Retrieved September 14, 2007, from http://nces.ed.gov/pubs2006/2006184.pdf

36. Hsu, L. (2005). Teaching thinking and reasoning skills in a science course. In J. L. Higbee, D. B. Lundell, \& D. R. Arendale (Eds.), The General College vision: Integrating intellectual growth, multicultural perspectives, and student development (pp. 333-353). Minneapolis: University of Minnesota, General College, Center for Research on Developmental Education and Urban Literacy. Retrieved April 22, 2009 , from http://cehd.umn.edu/CRDEUL/pdf/TheGCVision/section3.pdf

37. James, P. A. (2005). Aesthetic, metaphoric, creative, and critical thinking: The arts in General College. In J. L. Higbee, D. B. Lundell, \& D. R. Arendale (Eds.), The General College vision: Integrating intellectual growth, multicultural perspectives, and student development (pp. 247-285). Minneapolis: University of Minnesota, General College, Center for Research on Developmental Education and Urban Literacy. Retrieved April 22, 2009, from http://cehd.umn.edu/CRDEUL/pdf/TheGCVision/section3.pdf

38. James, P., \& Kader, T. (2008). Practicing Universal Instructional Design in visual art courses. In J. L. Higbee \& E. Goff (Eds.), Pedagogy and student services for institutional transformation: Implementing universal design in higher education (pp. 87-105). Minneapolis: University of Minnesota, Center for Research on Developmental Education and Urban Literacy. Retrieved April 24, 2009, from http://cehd.umn.edu/passit/docs/PASS-IT-Book.pdf

39. Johnson, D. M., \& Fox, J. A. (2003). Creating curb cuts in the classroom: Adapting Universal Design principles to education. In J. L. Higbee (Ed.), Curriculum transformation and disability: Implementing universal design in higher education (pp. 7-21). Minneapolis: University of Minnesota, General College, Center for Research on Developmental Education and Urban Literacy. Retrieved November 29, 2007, from http://cehd.umn.edu/CRDEUL/books-ctad.html

40. Kalivoda, K. S., \& Higbee, J. L. (1995). A theoretical model for the prediction of faculty intention to accommodate disabled students. Journal of the Mid-American Association of Educational Opportunity Program Personnel, 7(1), 7-22.

41. Kalivoda, K. S., \& Higbee, J. L. (1998). Influencing faculty attitudes toward accommodating students with disabilities: A theoretical approach. The Learning Assistance Review, 3 (2), 12-25.

42. Kalivoda, K. S., Totty, M. C., \& Higbee, J. L. (2009). Appendix E: Access to information technology. In J. L. Higbee \& A. A. Mitchell (Eds.), Making good on the promise: Student affairs professionals with disabilities (pp. 226-232). Lanham, MD: University Press of America and ACPA - College Student Educators International. 
43. Kinney, D. P., \& Kinney, L. S. (2008). Computer-mediated learning in mathematics and Universal Instructional Design. In J. L. Higbee \& E. Goff (Eds.), Pedagogy and student services for institutional transformation: Implementing universal design in higher education (pp. 155-163). Minneapolis: University of Minnesota, Center for Research on Developmental Education and Urban Literacy. Retrieved April 24, 2009, from http://cehd.umn.edu/passit/docs/PASS-IT-Book.pdf

44. Kinney, D. P., Kinney, L. S., \& Robertson, D. E. (2005). Learning mathematics through computermediated instruction. In J. L. Higbee, D. B. Lundell, \& D. R. Arendale (Eds.), The General College vision: Integrating intellectual growth, multicultural perspectives, and student development (pp. 299-318). Minneapolis: University of Minnesota, General College, Center for Research on Developmental Education and Urban Literacy. Retrieved April 22, 2009, from http://cehd.umn.edu/CRDEUL/pdf/TheGCVision/section3.pdf

45. Knox, D. K., Higbee, J. L., Kalivoda, K. S., \& Totty, M. C. (2000). Serving the diverse needs of students with disabilities through technology. Journal of College Reading and Learning, 30(2), 144-157.

46. Lee, C., \& Jackson, R. (1992). Faking it: A look into the mind of a creative learner. Portsmouth, NH: Boynton/Cook.

47. Miksch, K. L. (2008). Universal Instructional Design in a legal studies classroom. In J. L. Higbee \& E. Goff (Eds.), Pedagogy and student services for institutional transformation: Implementing universal design in higher education (pp. 107-112). Minneapolis: University of Minnesota, Center for Research on Developmental Education and Urban Literacy. Retrieved April 24, 2009, from http://cehd.umn.edu/passit/docs/PASS-IT-Book.pdf

48. $\quad$ Pedagogy and Student Services for Institutional Transformation (PASS IT). (n.d.). Minneapolis: University of Minnesota, College of Education and Human Development. Retrieved April 28, 2009, from http://cehd.umn.edu/passit/

49. Pedelty, M. (2008). Making a statement. In J. L. Higbee \& E. Goff (Eds.), Pedagogy and student services for institutional transformation: Implementing universal design in higher education (pp. 79-85). Minneapolis: University of Minnesota, Center for Research on Developmental Education and Urban Literacy. Retrieved April 24, 2009, from http://cehd.umn.edu/passit/docs/PASS-IT-Book.pdf

50. Rose, D. H. (2001). Universal design for learning: Deriving guiding principles from networks that learn. Journal of Special Education Technology, 16(2), 66-67.

51. Rose, D. H., Harbour, W. S., Johnston, C. S., Daley, S. G., \& Abarbanell, L. (2008). Universal design for learning in postsecondary education: Reflections on principles and their application. In S. E. Burgstahler \& R. C. Cory (Eds.), Universal design in higher education: From principles to practice (pp. 45-59). Cambridge, MA: Harvard Education Press.

52. Rose, D. H., \& Meyer, A. (2000). Universal design for learning. Journal of Special Education Technology, 15(1), 67-70.

53. Scott, S. S., McGuire, J. M., \& Shaw, S. F. (2001). Principles of universal design for instruction. Storrs: University of Connecticut, Center on Postsecondary Education and Disability.

54. Scott, S. S., McGuire, J. M., \& Shaw, S. F. (2003). Universal design for instruction: A new paradigm for adult instruction in postsecondary education. Remedial and Special Education, 24(6), 369-379.

55. Shapiro, B. (2008). A basic introduction to Web content accessibility. In E. Goff \& J. L. Higbee (Eds.), Pedagogy and student services for institutional transformation: Implementation guidebook for faculty and instructional staff (pp. 78-80). Minneapolis: University of Minnesota, College of Education and Human Development. Available soon at http://cehd.umn.edu/passit/

56. Sharby, N., \& Roush, S. E. (2008). The application of Universal Instructional Design in experiential education. In J. L. Higbee \& E. Goff (Eds.), Pedagogy and student services for institutional transformation: Implementing universal design in higher education (pp. 305-320). Minneapolis: University of Minnesota, Center for Research on Developmental Education and Urban Literacy. Retrieved April 24, 2009, from http://cehd.umn.edu/passit/docs/PASS-IT-Book.pdf

57. Silver, P., Bourke, A., \& Strehorn, K. C. (1998). Universal Instructional Design in higher education: An approach for inclusion. Equity and Excellence in Education, 31(2), 47-51.

58. Smith, K.L. (1997). Preparing faculty for instructional technology: From education to development to creative independence. Cause/Effect, 20(3), 36-44. 
59. Spencer, A. M., \& Romero, O. (2008). Engaging higher education faculty in universal design: Addressing the needs of students with invisible disabilities. In S. E. Burgstahler \& R. C. Cory (Eds.), Universal design in higher education: From principles to practice (pp. 145-156). Cambridge, MA: Harvard Education Press.

60. Staats, S. K. (2005). Multicultural mathematics: A social issues perspective in lesson planning. In J. L. Higbee, D. B. Lundell, \& D. R. Arendale (Eds.), The General College vision: Integrating intellectual growth, multicultural perspectives, and student development (pp. 185-199). Minneapolis: University of Minnesota, General College, Center for Research on Developmental Education and Urban Literacy. Retrieved April 22, 2009, from http://cehd.umn.edu/CRDEUL/pdf/TheGCVision/section2.pdf

61. Stone, M. E., \& Jacobs, G. (Eds.). (2006). Supplemental Instruction: New visions for empowering student learning. New Directions for Teaching and Learning, No. 106. San Francisco: Jossey-Bass.

62. Tregoning, M. E. (2009). Being an ally in language use. In J. L. Higbee \& A. A. Mitchell (Eds.), Making good on the promise: Student affairs professionals with disabilities (pp. 173-176). Lanham, MD: University Press of America and ACPA—College Student Educators International.

63. Uncertain welcome [video]. (2002). Minneapolis: University of Minnesota, General College and Disability Services. Retrieved December 11, 2006, from http://cehd.umn.edu/passit/videos.html

64. UN Enable (n.d.). Rights and dignity of persons with disabilities. Retrieved April 23, 2009, from http://www.un.org/disabilities/

65. U.S. Department of Education. (n.d.). Demonstration projects to ensure students with disabilities receive a quality higher education. Retrieved August 27, 2006, from http://www.ed.gov/programs/disabilities

66. Wieland, A. (2009). An invisible identity: Learning disability. In J. L. Higbee \& A. A. Mitchell (Eds.), Making good on the promise: Student affairs professionals with disabilities (pp. 70-76). Lanham, MD: University Press of America and ACPA - College Student Educators International.

67. Zuñiga, X. (2003). Bridging differences through dialogue. About Campus, 7(6), 8-16. 


\section{$\underline{\text { NOTES }}$}

